\title{
Model of the On-Line Course for Training Master Students Majoring in Mathematics for Teaching at University
}

\author{
Iryna Lovianova ${ }^{1}$, Kateryna Vlasenko ${ }^{2}$, Iryna Sitak $^{3}$, Iryna Akulenko ${ }^{4}$, Oksana Kondratyeva ${ }^{5, *}$ \\ ${ }^{1}$ Department of Mathematics and Teaching Methods, Kryvyi Rih State Pedagogical University, Ukraine \\ ${ }^{2}$ Department of Mathematics and Modeling, Donbas State Engineering Academy, Ukraine \\ ${ }^{3}$ Department of Mathematics and Computer Technologies, the Institute of Chemical Technologies of the Volodymyr Dahl East \\ Ukrainian National University, Ukraine \\ ${ }^{4}$ Department of Algebra and Calculus, Educational-Scientific Institute of Informational and Educational Technologies, Bohdan \\ Khmelnytsky National University, Ukraine \\ ${ }^{5}$ Department of Geodesy, Land Management and Building Structures, Cherkassy State Technological University, Ukraine
}

Received May 7, 2020; Revised July 4, 2020; Accepted July 20, 2020

\section{Cite This Paper in the following Citation Styles}

(a): [1] Iryna Lovianova, Kateryna Vlasenko, Iryna Sitak, Iryna Akulenko, Oksana Kondratyeva, "Model of the On-Line Course for Training Master Students Majoring in Mathematics for Teaching at University," Universal Journal of Educational Research, Vol. 8, No. 9, pp. 3883 - 3894, 2020. DOI: 10.13189/ujer.2020.080912

(b): Iryna Lovianova, Kateryna Vlasenko, Iryna Sitak, Iryna Akulenko, Oksana Kondratyeva (2020). Model of the On-Line Course for Training Master Students Majoring in Mathematics for Teaching at University. Universal Journal of Educational Research, 8(9), 3883 - 3894. DOI: 10.13189/ujer.2020.080912.

Copyright $\bigcirc 2020$ by authors, all rights reserved. Authors agree that this article remains permanently open access under the terms of the Creative Commons Attribution License 4.0 International License

\begin{abstract}
This article considers the issue of on-line training of Master students, majoring in Mathematics (Speciality code in Ukrainian educational system "014.04 Secondary Education. Mathematics") and preparing them for teaching at University. The research papers and resources, focusing on the vocational bent of on-line training of undergraduate students majoring in Mathematics have been analyzed in this paper. The present paper describes designing the structure and components for the on-line course "Methods for Teaching Mathematics to Students at Technical Universities", which is in open access on the educational platform "Higher School Mathematics Teacher". This article presents the analysis of the survey results, in which 107 students in their first and second year of studying took part, which allowed defining the content of the course. The model is presented as a polyhedron, vertices, faces and edges of which show structural elements of the model and relations between them. The paper also introduces the analysis of the internship syllabi at Ukrainian universities and aims at defining the criteria for assessing learning performance of the on-line course users. It also considers the impact of the course on the efficiency of training 112 Master students in
\end{abstract}

their second year of study, when they do their assistant internship at technical universities. The qualitative and quantitative analysis of the results of the experiment proved the efficiency of introducing the course into the process of practical training of Master students. The interns who joined the course, showed a better understanding of how to motivate students when teaching Mathematics to them. They also showed better results in applying active learning tools and techniques for teaching Mathematics, as well as in managing the audience through information technologies and communication strategies.

Keywords Practical Teacher Training, Master Students, Mathematics, On-line Course, Theoretical Model

\section{Introduction}

\subsection{Problem Statement}

Upon obtaining a Master's degree (Speciality code in Ukrainian educational system "014.04 Secondary 
Education. Mathematics"), graduates are entitled to work as Mathematics teachers at school or University. The professional activity of a University Mathematics teacher requires certain competencies. For instance, Hilbrun [1] singled out the competencies, necessary for a Mathematics teacher at a technical University, considering that professional activity implies: the ability to apply knowledge in Mathematics, Science and Engineering; the ability to do projects and experiments as well as undertake analysis and interpret the findings; the ability to design a system, a component or a process in order to meet the desired needs within realistic constraints, such as economic, environmental, social, political, ethical, safety and health care; the ability to function in multidisciplinary teams; the ability to determine, design and solve engineering problems; awareness of professional and ethical responsibility; the ability to communicate efficiently; well-rounded education, necessary for understanding the impact, which engineering solutions might have in global economic, environmental and societal contexts; acknowledging the ability and the need for life-long learning. In order to master these competencies, a Mathematics teacher requires special training. Hilbrun [1] considers that using thematic research, the introduction of realistic aspects of internship into the syllabus are especially efficient in training Master students, since graduate students lack in practical competence.

Searching the solution to the aforementioned problem has always been of interest to researchers. Mehnert, Wyschkon [2] stated the lack of connections between the elements "theory-practice" in the learning process and its vocational bent. Szempruch [3] focused on the necessity to integrate pedagogical knowledge into major subjects and strengthening the connection between theory and practice through departure from conventional algorithms in teacher training. Batechko [4] highlighted the fact that the traditional system of training University teachers no longer meets social needs at a proper level. Popov, Puchkova, Ustina [5] put emphasis on the importance of integrating theoretical knowledge into its practical implementation. In their study such researchers as Vlasenko et al. [6] supported the conclusion that the issue of practical training of University Mathematics teachers is faced globally. Korenova [7], Lin, Tseng, Chiang [8] did research into the efficiency of applying blended learning when training would-be Mathematics teachers. The researchers described how the students along with classroom tutorials obtained on-line support. The findings of the experiment proved that the students felt more motivated in a blended learning environment. Research by Holzweiss, Polnick, Lunenburg [9] adds to the aforementioned results. Scrutinizing the students' responses concerning such type of learning, the researchers singled out the most typical answer which is the provision of mobility conditions and having timely support from a tutor.

Master students majoring in Mathematics point at the lack of such support. For most students doing the internship, the challenges which they face, turn out to be unexpected. Feeling the lack of proper training for such kind of internship, the students voice their willingness to get on-line counseling and support. The above mentioned adds to the relevance of the research into the on-line practical training.

\subsection{Analysis of the Recent Research and Publications}

Among the surveys which cover the methods of training Master students majoring in Mathematics, there are various types of research into the level of their readiness for professional activity. When determining the conditions for developing readiness for professional and pedagogical cooperation within the system of higher education, Tolegen et al [10] described such levels of readiness of future teachers as following: reproductive, reproductive and creative, creative. Lyubov et al. [11] did the research into regularities and the logical structure of designing and implementing a humanitarian component of students' professional training as a four-step algorithm: motivational and value-based, focus-based, operational activity, control and correction. The researcher also highlighted the necessity to use educational materials and the importance of searching interactive learning strategies which contribute to developing professional competencies in students and enhance their motivation for learning.

The researchers also focus their attention on the modes of teacher training. Kushnir et al. [12] presented their experience in running on-line workshops as a method of developing teachers' readiness for implementing innovations. Popov, Puchkova, Ustina [5] consider that programs for on-line courses must be designed, aiming at creating conditions where a student becomes a subject of the learning process, therefore contributing to developing the students' psychological readiness for professional activity. Nurzhynska and Chernobrovkina [13] emphasize the fact that dynamic development of e-learning improves educational process and urges the necessity to create on-line libraries, to promote systematic on-line communication with a teacher, participation in webinars. Summarising the on-line learning experience of both, students and teachers, Austin, Gustafson [14], Vlasenko et al. [15] focus on the possibility to ensure improving the qualification of Mathematics teachers through on-line courses. Gaff [16] and other developers of the courses justified the idea, that on-line education can contribute to students mastering the core types of practical teaching activities, applied when teaching Mathematics and solving certain problems.

According to estimates by Rifandi [17], young Mathematics teachers are neither very good at understanding internal subject connections between different sections of Mathematics, nor at finding proper modes and methods for demonstrating these connections to their students. Moreover, the research papers in place focus 
on the problem of considering the peculiarities of the course content.

The analysis of research by Vlasenko et al. [18] shows, that young teachers do not fully understand the necessity to take into consideration other subjects when teaching Mathematics. The researchers put emphasis on the fact that young specialists lack in certain communication skills and abilities for instance, the ability to maintain positive motivation in their students to study Mathematics. Researchers stress on the importance of showing practical opportunities which mathematical methods give to future engineers and the fact that teachers lack in such knowledge. Mao et al. [19] confirm that at the beginning of their career path, Mathematics teachers encounter problems, selecting the means for visualizing mathematical notions and do not focus the students' attention on building mathematical models of real processes.

The academic sources consider certain ways of solving the defined problems. To give Master students understanding about the integrative nature of the Mathematics course at a technical university, Kolomiets et al. [20] believe it is important to show the students internal subject connections between such sections of the course as Elements of Linear and Vector Algebra, Analytical Geometry, Mathematical Analysis. The researchers justify the relevance and give recommendations to devise professionally-orientated tasks as a basis for mastering specific disciplines.

As Rifandi [17] considers, using mathematical methods when solving tasks in building, machine-building, mining, contributes to enhancing the students' motivation to study Mathematics. Ochkov, Orlov, Voloshchuk [21] justify studying mathematical models of the engineering processes when teaching Mathematics and show how the usage of MathCad helps to avoid complex calculations.

Visualising mathematical models in $3 \mathrm{D}$, using Mathematica is also considered in the papers by Armbrust et al [22]. Mell and Grance [23], where they describe the relevance of using cloud computing in order to analyse and interpret the results of the calculated mathematical models. Mao et al. [19] suggest using MatLab for supporting engineering work. Lima et al. [24] studied the problem of the efficient management of interdisciplinary projects in mathematical education of engineers. Powell and Weenk [25] defined project-led engineering education, describing in detail the objectives and principles of this learning technology. No doubt, training of future Mathematics teachers requires their awareness and application of the existing scientific developments during their internship. According to Holzweiss, Polnick and Lunenburg [9], it becomes possible through designing and introducing courses in an on-line format.

Sharing the opinions of the researchers and being aimed at providing support to Mathematics Master students, who do their internship at technical universities, the team of the researchers designed an on-line course "Methods for Teaching Mathematics to Students at Technical Universities" [26] on the educational platform "Higher School Mathematics Teacher" [27]. This course is targeted at complementing the traditional training of the future Mathematics teachers with the opportunities, which on-line environment can offer. In the process of designing the course, the information, presented in Guide to Teaching Online Courses [28] was taken into account. This guide offers Guiding Questions for designing a course model (Figure 1) and states that this model is to become a framework, but it must be flexible and dynamic.

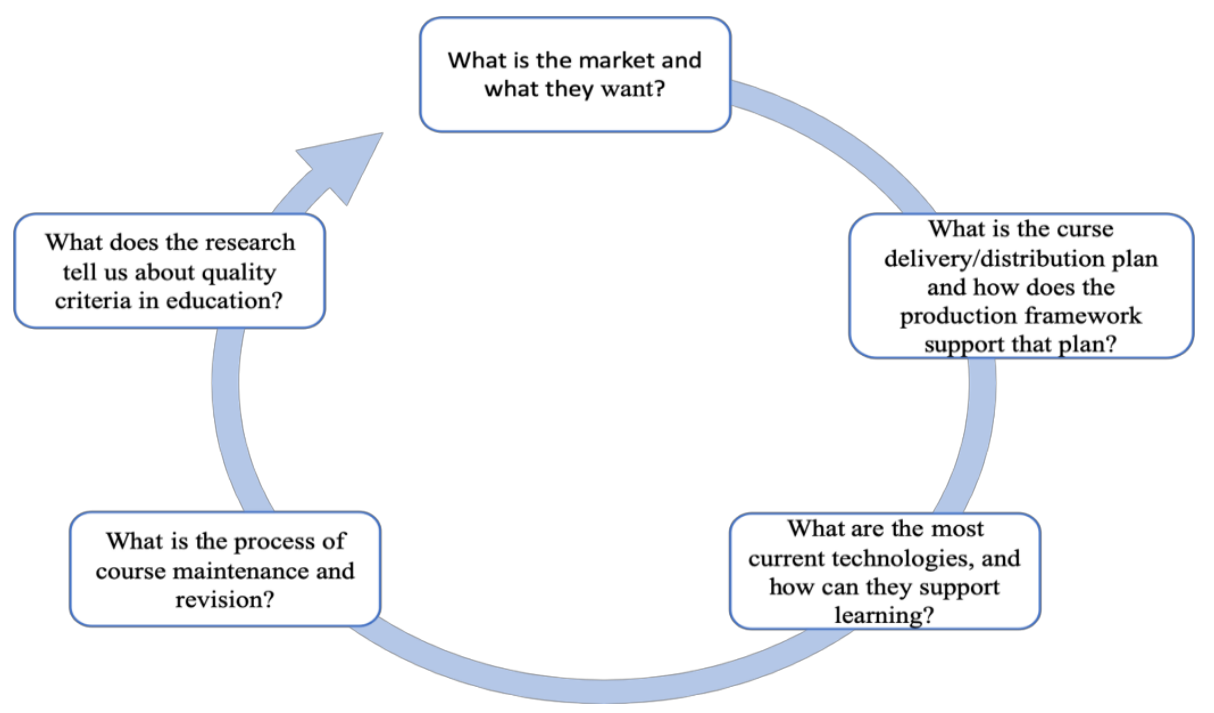

Figure 1. On-line Course Production Framework: Guiding Questions 
The objective of this paper is to do a theoretical analysis of the research papers and academic resources that describe the process of designing the structure and components of an on-line course; to design a theoretical model of the on-line course "Methods for Teaching Mathematics to Students at Technical Universities" [26]; to introduce the course into the practical training of Master students, majoring in Mathematics. In order to reach the objective it is necessary to take the following steps:

1) to define what problems both Master students face when doing their internship at technical universities and young teachers have at the beginning of their career path; to understand if it is possible to solve those problems through an on-line course;

2) to analyze the resources, which give guidance on designing the models of on-line courses and single out the ones, which can help to develop a theoretical model of the on-line course "Methods for Teaching Mathematics to Students at Technical Universities" [26];

3) to define the content of the course and assessment criteria for the course users;

4) to introduce the course into practical training of Master students; to check the efficiency of on-line training of Master students for teaching at universities.

\section{Materials and Methods}

The process of designing the on-line course "Methods for Teaching Mathematics to Students at Technical Universities" [26] encompassed three stages. At the first stage, the authors of the present study used the Deductive Content Analysis of the recommendations on how to design the models of on-line courses, offered by the experts [27] on teacher training. This analysis helped to define the constituents of the theoretical model of the on-line course "Methods for Teaching Mathematics to Students at
Technical Universities" [26]. The model was given content, taking into account certain recommendations (Table 1) from the above mentioned guidelines and guiding questions on on-line course production framework (Figure $1)$.

Table 1. The recommendations on how to develop models of on-line courses

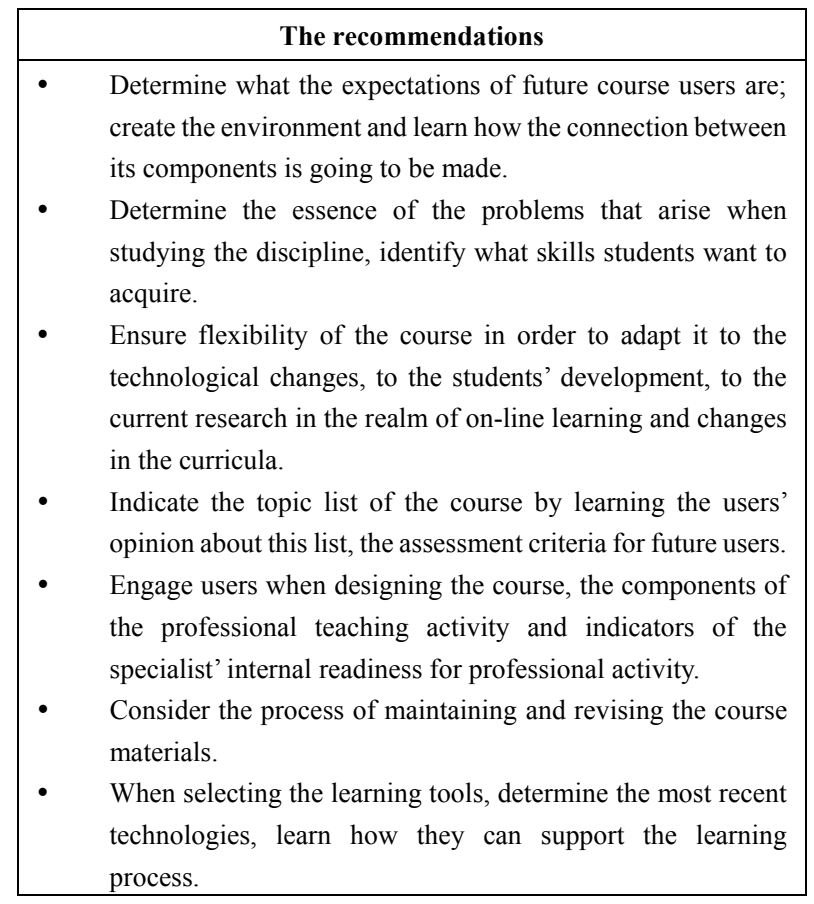

The analysis of the sources and the guidelines on designing similar on-line courses helped the authors of this paper to define the structural elements of the model (Figure 2):

(1). Methodological environment (upper face);

(2). Technologies of the learning environment (lower face);

(3). Components of professional training (lateral faces) motivation and value-based, operational and activity-related, controlling and corrective. 


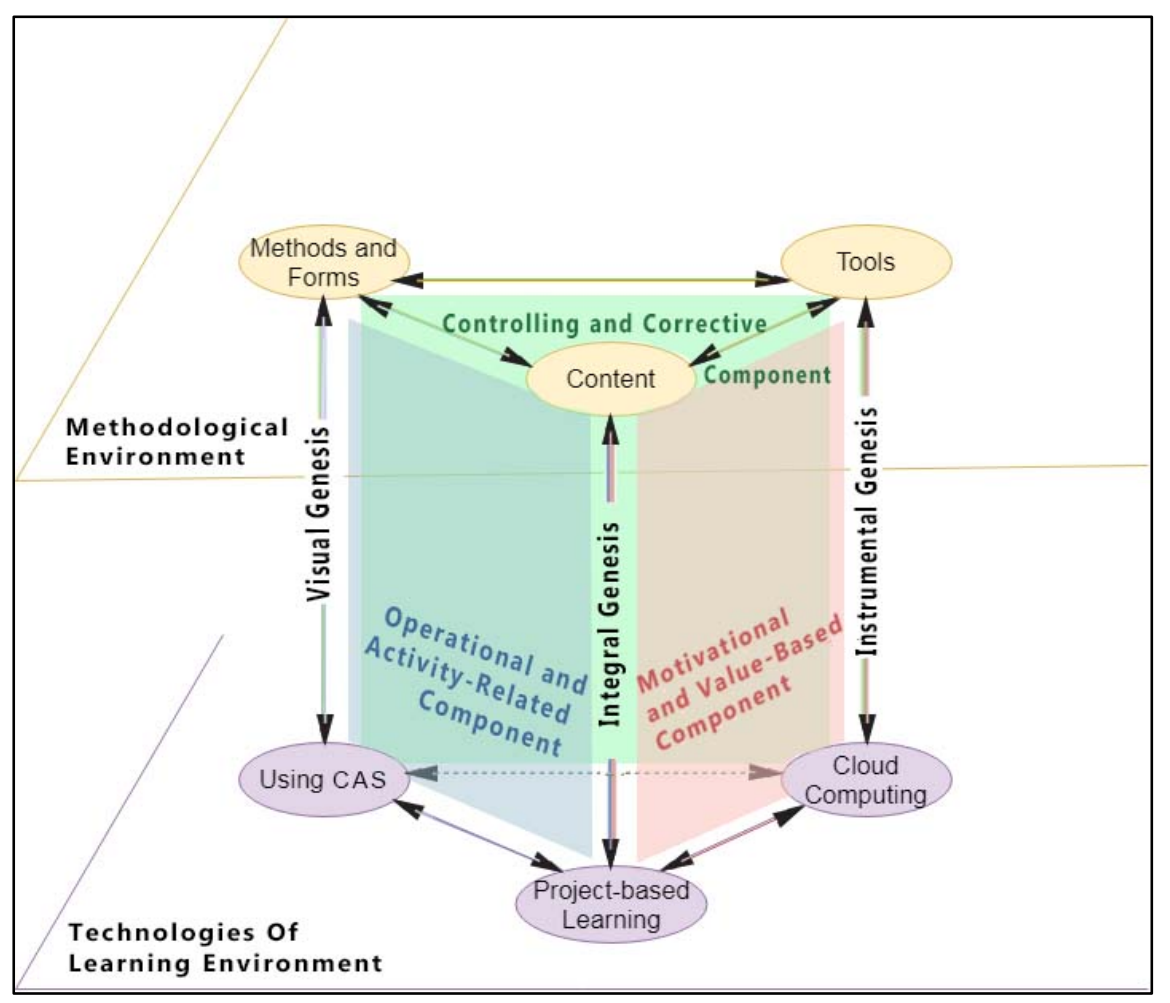

Figure 2. The theoretical model of the on-line course "Methods for Teaching Mathematics to Students at Technical Universities"

At the second stage, detailing the structural elements of the model took place. The opinions of the prospective users of the on-line course were taken into account, so that the final product would meet their expectations. The questionnaire containing 12 questions was devised with the help of an on-line service in open access and placed on the platform "Higher school mathematics teacher" [28], https://docs.google.com/forms/d/1eRP7HjR8K6i9hHGS8 PTGvw-IHcQq2BRDT-1FLz5Y5sI/viewform?edit_reques ted $=$ true. The validity of the received data is ensured by the fact, that the survey was anonymous and there was no external influence on the respondents' choice. The survey was aimed at defining the problems, which the students faced during their internship; the Master students' awareness of the methodological specifics of using active learning technologies when teaching Mathematics; understanding by future teachers the opportunities that Computer Algebra Systems (CAS) and cloud technologies give for the development of the new strategies and methodologies of teaching Mathematics-related subjects at technical universities. The course developers were also aimed at learning about the degree of awareness of the prospective course users concerning the possibility to use certain technologies in teaching Mathematics. The respondents' answers added value to defining the course content. When giving answers to the questions, the students showed willingness to learn about the components of professional training, specific kinds of a teacher's activities as well as indicators of internal readiness for professional activity. The analysis of the students' responses will be presented in the section Results.

"What are the most relevant technologies and how can they support the learning process?" - The answer to this question was complemented by the respondents' willingness to master the process of using modern learning technologies, so the vertices of the lower faces of the model represent CAS, systems of cloud computing, project-based learning. Establishing the connections between the methodological environment and technologies of the learning environment is presented on the lateral edges of the model as visual, instrumental, integral genesis.

"What does the process of managing and reviewing the course materials mean?" - Searching an answer to this question resulted in creating a forum, which is run by the course tutors. When uploading the course materials, the tutors raised the issue on the forum, thus defining and checking the quality of the content and the importance of providing the users with assistance. Constant review of the course materials was also done by its tutors and users, who were willing to participate in developing content for the course. The analysis of the respondents' answers helped the course developers to define:

1) a list of topics for the on-line course that would be interesting for students;

2) modes of presenting the learning material;

3) the degree of a tutor's assistance and ways to provide it;

4) the mode of working with the on-line course and the timeframe, necessary for learning how to work with it. 
Table 2. The analysis of the Internship Program for Master students

\begin{tabular}{|c|c|}
\hline $\begin{array}{l}\text { Assistant Internship Program in Kryvyi Rih } \\
\text { State Pedagogical University [29] }\end{array}$ & $\begin{array}{l}\text { To learn about the basic principles, modes and methods of teaching special disciplines at } \\
\text { University; to develop the ability to plan and manage educational and methodological } \\
\text { activity of a teacher; to master the methods of designing educational materials in order to } \\
\text { use them in the process of training students, who obtain a Bachelor's degree; to master the } \\
\text { methods of running various types of classes at University and managing students' self-study } \\
\text { work; to develop professional teacher competencies; to develop personal qualities, } \\
\text { necessary for the job. }\end{array}$ \\
\hline $\begin{array}{l}\text { Scientific and Pedagogical (assistant) } \\
\text { Internship Program in Cherkassy National } \\
\text { University named after Bohdan } \\
\text { Khmelnitsky [30] }\end{array}$ & $\begin{array}{l}\text { To draft plans, prepare and run seminars, tutorials; to do methodological analysis of the } \\
\text { educational material in order to anticipate possible difficulties in its acquisition by students; } \\
\text { to draft educational materials for seminars, tutorials and self-study work of students. }\end{array}$ \\
\hline $\begin{array}{l}\text { Scientific and Pedagogical Internship } \\
\text { Program in National Pedagogical } \\
\text { Dragomanov University [31] }\end{array}$ & $\begin{array}{l}\text { To develop own skills and abilities in future scientific pedagogical activity: to draft plans of } \\
\text { lectures, to give the lectures in Mathematics; to draft notes and run tutorials, seminars or } \\
\text { laboratory works in accordance with the notes }\end{array}$ \\
\hline $\begin{array}{l}\text { Internship Program for Master students in } \\
\text { Berdyansk State Pedagogical University } \\
\text { [32] }\end{array}$ & $\begin{array}{l}\text { To develop relevant professional teaching competencies in University teachers; to develop } \\
\text { the ability to manage the basic modes of arranging the learning process at University, using } \\
\text { modern technologies and teaching methods; to refine the teaching experience, ethical } \\
\text { qualities in a University teacher, to develop individual creative teaching style and } \\
\text { willingness to pursue life-long learning. }\end{array}$ \\
\hline
\end{tabular}

At the third stage, the course developers also evaluated the efficiency of introducing the course into the process of training Master students. For this purpose, the comparative analysis of the students' performance was conducted. The students were in their second year of studying and doing their assistant internship. Before the internship started, the students in the experimental group were offered to enroll for the course "Methods for Teaching Mathematics to Students at Technical Universities" [26]. The students in the control group were doing their internship without enrolling for this course. The same tutors were involved into assessing the performance of the students in both groups and the criteria for assessing the users' activity were preliminary defined. For this purpose the authors of this paper applied the Inductive Content Analysis Method of the Internship Programs for Master students majoring in Mathematics ("014.04 Secondary Education. Mathematics") at some Ukrainian Universities. The findings of the analysis are presented in Table 2.

The analysis of the internship programs in the aforementioned Universities allowed the authors to define in their research the criteria for assessing the activity of the on-line course users:

- Academic and pedagogical activity (the ability to manage the basic modes of teaching Mathematics at University);

- Methodological activity (the ability to undertake methodological analysis of educational materials and draft materials for various types of classes);

- Integrative activity (the ability to select and apply modern technologies and methods of teaching);

- Professional activity (obtaining teaching experience, developing ethical qualities in a University teacher, individual creative teaching style as well as willingness to pursue life-long learning.).

Using these criteria, the tutors assessed the activities of the on-line course users after introducing the course into the students' practical training.

\section{Results}

Surveying the students was done when defining the components of the methodological aspect (upper edge) of the on-line course model (Figure 2). The $1^{\text {st }}$ and $2^{\text {nd }}$ year Master students from Kryvyi Rih State Pedagogical University, Sumy State Pedagogical University named after A. Makarenko, National Pedagogical Drahomanov University, Berdyansk State Pedagogical University, Vinnytsia Mykhailo Kotsiubynskyi State Pedagogical University participated in the survey as well as those who obtained a Master degree earlier. There were 107 respondents in total of whom $36,8 \%-1^{\text {st }}$ year Master students, $47,4 \%-2^{\text {nd }}$ year Master students, $15,8 \%-$ graduate students.

Table 3. The students' choice of the topics necessary for methodological training of teachers within the framework of the course "Methods Of Teaching Mathematics At Technical Universities" [26]

\begin{tabular}{|c|l|c|}
\hline № & \multicolumn{1}{|c|}{ Course Topic } & $\begin{array}{c}\% \text { of } \\
\text { respondents }\end{array}$ \\
\hline 1. & $\begin{array}{l}\text { Methodological basics of teaching } \\
\text { Mathematics at University }\end{array}$ & $89,5 \%$ \\
\hline 2. & $\begin{array}{l}\text { Methods of running tutorials, seminars, } \\
\text { laboratory works }\end{array}$ & $82,5 \%$ \\
\hline 3. & $\begin{array}{l}\text { Practical implementation of the } \\
\text { methodological project system }\end{array}$ & $78,9 \%$ \\
\hline 4. & $\begin{array}{l}\text { Arrangement of the learning process within } \\
\text { the framework of Mathematics teacher } \\
\text { training }\end{array}$ & $78,9 \%$ \\
\hline 5. & $\begin{array}{l}\text { Methods of control and assessment of the } \\
\text { level of the students' competence }\end{array}$ & $77,2 \%$ \\
\hline 6. & $\begin{array}{l}\text { Methods of using cloud computing when } \\
\text { teaching Higher Mathematics to students }\end{array}$ & $71,9 \%$ \\
\hline 7. & Methods of giving lectures in Mathematics & $70,2 \%$ \\
\hline 8. & $\begin{array}{l}\text { Methods of managing students' self-study } \\
\text { work }\end{array}$ & $66,7 \%$ \\
\hline 9. & $\begin{array}{l}\text { Methods of designing and developing a } \\
\text { Mathematical project }\end{array}$ & $66,7 \%$ \\
\hline 10. & $\begin{array}{l}\text { Cloud computing technologies in teaching } \\
\text { Higher Mathematics to students }\end{array}$ & $61,4 \%$ \\
\hline
\end{tabular}

The respondents were offered to contribute to creating the content for the on-line course and to rank the list of 
topics according to their importance. The topics that are important for methodological preparation of a Mathematics teacher at a technical university, or the ones which make such preparation incomplete, were defined in the following way (see Table 3).

Choosing the topics for the course was coupled with defining the modes and methods of presenting the learning material. The analysis of the answers shows that:

1) $87 \%$ of the respondents are willing to have video support of the theoretical material;

2) $92 \%$ of the Master students want to use close-ended tests in order to check their academic achievements;

3) $92 \%$ of the respondents would like to have an opportunity to share their opinions on the open fora;

4) $75 \%$ of the students want to keep in contact with a tutor who would control and correct the process of mastering the course;

5) $59,6 \%$ are ready to follow a personalized schedule when working with the course;

6) $100 \%$ of the respondents are willing to use the course when doing their assistant internship.

To define the technologies of the learning environment (lower edge) of the on-line course model (Figure 2), all the trends in teaching Mathematics at technical universities were considered. They are active learning technologies; engaging CAS for visualizing and analyzing mathematical objects; usage of Cloud-Based Mathematical Software for calculating mathematical models.

Before introducing the methodological possibility and the specifics of using certain active learning technologies when teaching Mathematics, the level of awareness of future course users about those possibilities and specifics was considered. The students were offered to select active learning technologies which, in their opinion, should be applied when teaching Mathematics at technical universities. Figure 3 presents the results of the answers.

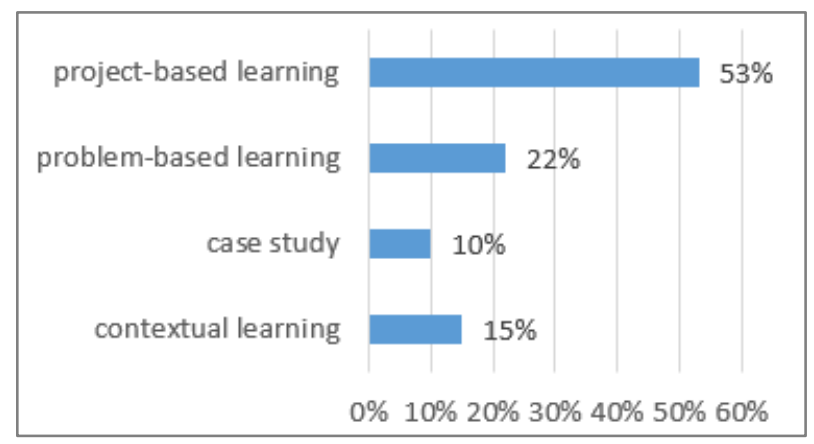

Figure 3. Ranking of active learning technologies by the level of their engagement into teaching Mathematics

Most respondents selected the project method and indicated that they have some theoretical knowledge about it. They also noted that practical application of this method is the most familiar to them (Figure 4). Thus, one of the vertices of the on-line course model was chosen.

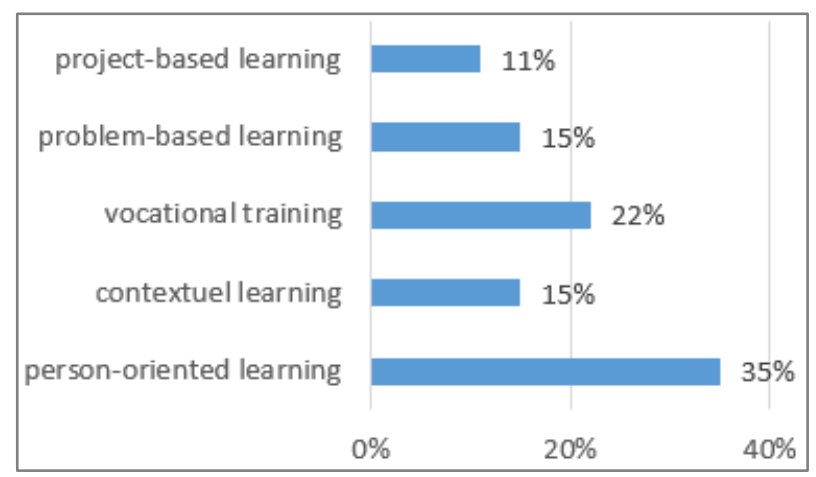

Figure 4. The level of the respondents' awareness about practical application of the active learning methods when teaching Mathematics

When choosing CAS, the awareness of the prospective course users about various systems was taken into account. It was critical to focus on the methodological aspects of using CAS in teaching Mathematics. The respondents were offered several most widely used CAS and were asked to select those ones which they use most frequently. The results of the survey are presented in Figure 5.

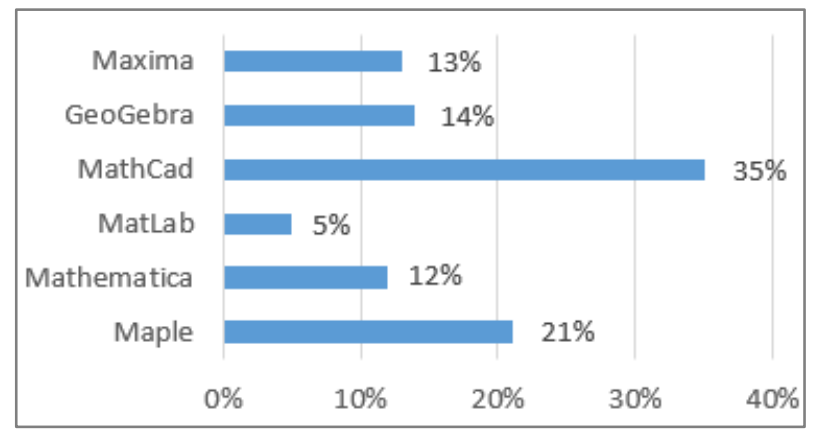

Figure 5. The level of the respondents' awareness about CAS

MathCad was selected as an example to showcase the opportunities which are given by the usage of CAS when teaching Mathematics at technical universities. The students were eager to know how to use MathCad during classroom tutorials.

The authors of this paper were aimed to define the awareness level of Master students about cloud-based tools in teaching Mathematics and came to the conclusion that the respondents have no clear understanding about the methodological approaches and recommendations on how to use those tools. The vast majority of the respondents consider that using cloud calculators can hamper developing the skills of analysis and synthesis. 87\% of those respondents expressed their willingness to learn about Cloud-Based Mathematical Software and guidelines on how to use them, so as to arrange the interaction between tutors and students. Thus, we have two other vertices of the lower edge of the model (Figure 2). After designing and presenting the course materials according to the model, it was introduced into the assistant internship syllabus in 2019.

During 2019-2020 the impact of the course on the 
efficiency of the interns' practical training at technical universities was studied. 112 sophomores from the above mentioned universities were engaged into the experiment. During the internship the experimental group of 57 students was offered to join the course "Methods for Teaching Mathematics to Students at Technical Universities" [26]. The control group consisted of 55 Master students, who did the internship without joining the course. In order to have equivalent groups, at the beginning of the experiment the students with similar grades in Methods of Teaching Mathematics were chosen. The same tutors assessed the students in both groups.

In order to assess the students' results according to the criteria, described above, they were offered:

- to run a tutorial on the topic "Scalar and vector products of vectors" for the $1^{\text {st }}$ year students, majoring in Engineering (academic and educational activity);

- to devise a tutorial on the topic "Calculating bounds on the function" for the $1^{\text {st }}$ year students, majoring in Engineering (methodological activity);

- using CAS to draft a passport of a project in Mathematics for the students, majoring in Ecology and Energy Saving, (integrative activity);

- to develop a detailed plan of arranging individual work in Mathematics for the $1^{\text {st }}$ year students, majoring in Engineering (professional activity).

The interns' work was assessed in compliance with the following indicators (10 points for each).

1. Showing the necessity to study the topic for further learning of engineers; usage of customary symbols and terminology which ensure the fundamental character of Mathematics.

2. Showing internal and external subject connections of the topic.

3. Using practical tasks as examples of applying respective theoretical knowledge; relevance of such examples.

4. The level of the balance between scientific rigor, abstract nature of teaching and practical orientation of the information.

5. Managing the audience, their ability to maintain positive motivation to learn Higher Mathematics; creativity; using Cloud-Based Mathematical Software.

The results obtained are presented in the diagrams in Figures 6, 7, 8, 9 .

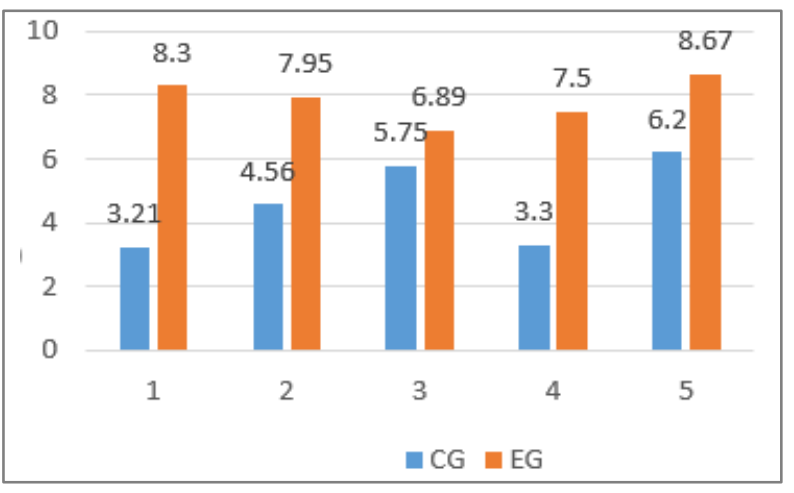

Figure 6. Assessing the students according to a criterion of scientific and educational activity

The professors who assessed the tutorial "Scalar and vector products of vectors" noticed that the interns in the experimental group demonstrated a better grasp of the methods, modes and tools of active learning; they selected more interesting practical tasks to motivate the students to study the topic and managed the audience properly; showed a higher level of understanding of the learning material in further training of future engineers; with the help of MathCad they devised better quality materials for the analysis of the mathematical models developed on the physical substance of scalar and vector products of vectors.

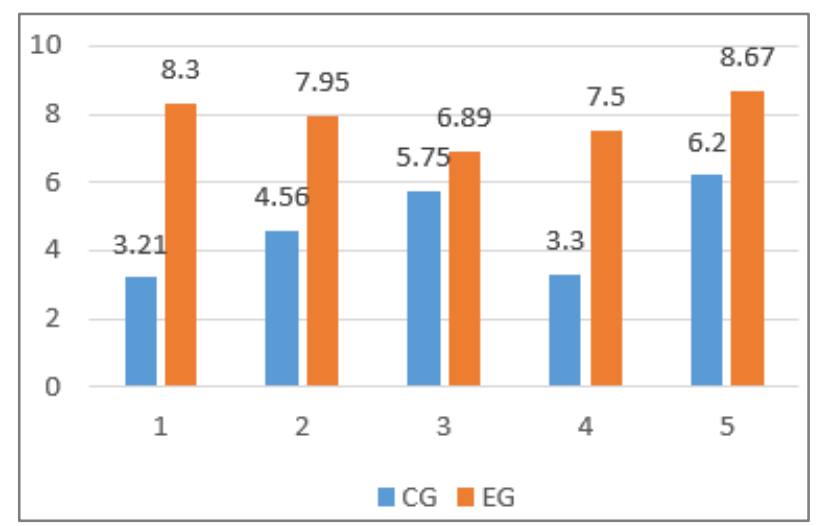

Figure 7. Assessing the students according to a criterion of methodological activity

When devising a tutorial, the students of the experimental group showed a highly developed skill to systematize the practical tasks; creativity in presenting to students how to solve those tasks using MathCad; drafted recommendations on how to arrange the class with the help of Google Classroom in case such a necessity arises. 


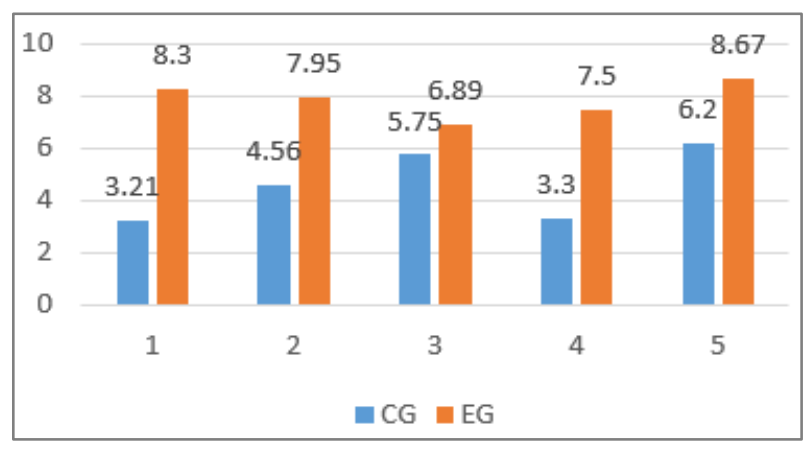

Figure 8. Assessing the students according to a criterion of integrative activity

When drafting a passport of the project in Mathematics for the students majoring in Ecology and Energy Saving, the students in the experimental group showed a much better skill to choose the topic of the project and a clear understanding of internal and external subject connections of Mathematics, a high level of creativity and teaching skills. Moreover, Master students in the experimental group offered a better system of assessing the individual work on the projects done by the groups.

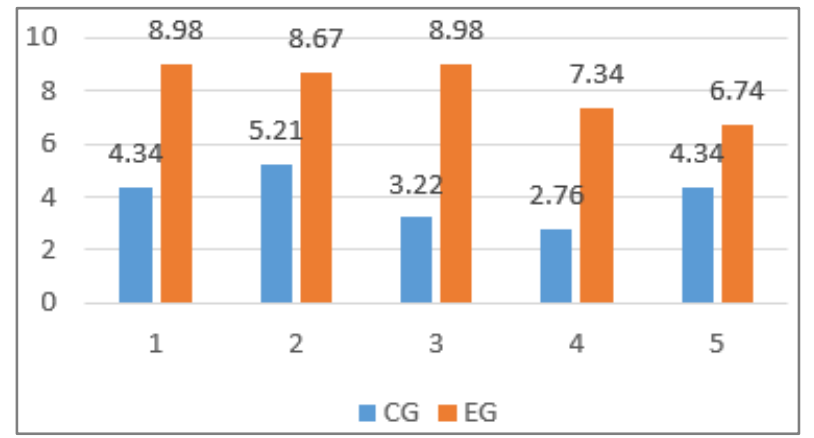

Figure 9. Assessing the students according to a criterion of professional activity

Master students in the experimental group were more creative at devising methodological recommendations on how to arrange individual work of students, using Maxima. The system was chosen by the students themselves, its usage for teaching Mathematics on the course wasn't demonstrated.

The Master students justified their choice by the presence of a menu in Ukrainian language, powerful mathematical tools, the opportunity to use it without any special preparation.

Thus, Master students showed better results in the four types of activity (the $1^{\text {st }}$ indicator - by $35 \%$, the $2^{\text {nd }}-$ by $27 \%$, the $3^{\text {rd }}-$ by $29 \%$, the $4^{\text {th }}-$ by $21 \%$, the $5^{\text {th }}-$ by $19 \%$ ), which proves the efficiency of engaging students into the on-line course "Methods for teaching mathematics to students at technical universities" [26].

Timeliness of designing the course "Methods for Teaching Mathematics to Students at Technical Universities" [26], its model and content were discussed and approved during the International Conference on
Sustainable Futures: Environmental, Technological, Social and Economic Matters (ICSF 2020) (Vlasenko et al. [33]).

\section{Discussion}

The idea to develop the Master students' readiness for teaching with the help of on-line tools was tested in a research by Moore et al. [34], where the author suggests designing and developing an on-line course, aimed at training teachers. The findings of the paper are discussed in a research by Santos and Carvalho [35]. The authors thereof cover the issues of training teachers and improving their competence with the help of Moodle. Describing the issue of arranging e-learning, Lovianova et al. [36] and Vlasenko et al. [37] offer models of courses in Mathematics.

As Porter [38] states, a model of an on-line course is to help in arranging the learning process on the Internet, contributing to efficient, holistic, and purposeful user experience. Perogonchuk [39] bases the model around the idea of applying several scientific approaches. When modelling, the researcher suggests applying a systemic approach, principles of humanity and professional orientation, flexibility, dynamism and variability. External factors (for instance, competence model of an expert in place) as well as internal ones (personal and professional qualities of a student) must be taken into consideration.

In course of designing a model of the on-line course "Methods for Teaching Mathematics to Students at Technical Universities" [26] relevant guidelines on designing on-line courses were analyzed and the findings thereof were used in the present research. The theoretical model of the on-line course was structured, following such components as the methodological environment, technologies of learning environment, components of professional training. The course model was presented as a polyhedron (Figure 2) where vertices, faces and edges were used to show the connections between the components of the model. The vertices of the polyhedron represent the content of the respective structural components of the methodological environment. If Master students acquire the learning material of this environment, they start to fully understand the practical application of the content, methods and modes of teaching Mathematics at a technical university. Recommendations from the researchers, their practical developments, guidelines from the course tutors make it possible to prepare Master students for classroom tutorials, to devise learning materials for teaching Mathematics. Functioning of such a component as technologies of the learning environment is based on using cloud computing, project-based learning. The necessity to use cloud technology was proved in a research by Mell and Grance [23], Armbrust et al. [22], Mao et al. [19]. The researchers stated that through giving user-friendly access to the network of computing resources which ensure and 
release from routine calculations, applying cloud technology contributes to intensifying calculations and focusing on more critical issues in the learning process. The course is to present the learning materials on how to apply practical developments of scientists, how to work with practical tips on using Google and web applications based on cloud computing. This will enable Master students to use the tools necessary for effective communication and collaborative work of academic staff and students.

When choosing the method of project-based learning, the research papers by Lima et al. [24], Van Hattum-Janssen [40], Fernandes et al. [41] were considered. Their findings prove that learning through doing projects results in a faster personal growth of students. It is also emphasized that this method is an important tool for the students' self-development and their self-management. In order to ensure the readiness of Master students for applying the project method in their teaching activity, the course is to describe the importance of doing projects when teaching Mathematics at technical universities. It also must have detailed presentations, video-lectures and tutorials on creating various types of projects.

Information technology also belongs to the tools that ensure professional development of future teachers. Thus, Karsenti [42], Lovianova et al. [36] stress on the importance of training future teachers to apply information technology, complemented by the scientists' recommendations in the training process. If would-be teachers elaborate methodological features of CAS usage through MathCad system, it can encourage them to search for ways and new strategies for teaching mathematical disciplines at technical universities.

To make the work with the methodological environment material and the learning environment technologies efficient, the lateral edges of the model are presented as visual, instrumental, integral genesis. Each of them helps to establish the connections between structural components of the model.

Research by Porter [38], Knowles and Kalata [43], Kebritchi et al. [44], Vlasenko et al. [45] justify the necessity to develop a questionnaire in order to identify the needs of the future course users. The importance of meeting the users' expectations is unanimously stated by the researchers. In order to provide the content (learning materials) for the components of the model, the authors of the present study maintained communication with future users through the surveys which were uploaded to the course forum. The analysis of the responses by the Master students majoring in Mathematics ("014.04 Secondary Education. Mathematics") confirmed their readiness to work on the course during their next internship.

\section{Conclusions}

The analysis of the resources and scientific research papers supported the conclusion concerning the necessity to design a theoretical model of the on-line course "Methods for Teaching Mathematics to Students at Technical Universities" [26]. Functioning of the model is ensured by the connections between the components of the environments, in which it operates, and is aimed at developing quality training of a technical University teacher through visual, instrumental and integral genesis. In order to determine the structural components of the model, their functions, content for methodological environment, the choice of technologies of learning environment, components of professional training, the researchers in the present study pursued to find answers to the questions that usually arise at the stage of designing on-line courses. When designing a course, its flexibility and adaptability to technological changes, to the students' development, to changes in on-line education and curricula must be taken into account. The course design and provisioning of content are to be coupled with constant surveys among its future users.

Active participation of graduate students (Master students majoring in Mathematics), who answered the questionnaires and provided their feedback on the forum of the platform "Higher School Mathematics Teacher" [28] enabled the implementation of the on-line course "Methods for Teaching Mathematics to Students at Technical Universities" [26] into practical training of the 2nd year Master students at teacher training Universities. The efficiency of engaging students into the course during their internship was proved experimentally. Master students in the experimental group demonstrated a better understanding of how to motivate students to learn the topics through the application of practical tasks and showing its external and internal subject connections. When designing and running classes, the Master students who used the course materials, showed better results of using active technologies of Mathematics learning, striking the balance between scientific approach to teaching and practical orientation of the information presented. The experiment fixed that the Master students who had an opportunity to get support from the course tutors showed better skills of managing the audience through understanding methodological opportunities of CAS for visualizing and analyzing mathematical objects, the usage of cloud-based Mathematical software for calculating mathematical models.

The direction for further research is to describe the process of arranging the learning activity of the students who are trained to be Mathematics teachers through the work with the on-line course "Methods for Teaching Mathematics to Students t Technical Universities" [26].

\section{Acknowledgments}

The authors of the present study are grateful to all the teachers and students, who contributed their time and 
effort and added value to this research through their participation in the survey.

\section{REFERENCES}

[1] T. Hilburn. Preparing students for professional practice, Online available from https://conferences.computer.org/cse et/2013/slides/CS2013CSEETKeynote.-Hilburn.pdf

[2] H. Mehnert, U. Wyschkon. Why does teacher training have to take place at the university? In: Focus: Teacher Training. Bayer M., Carle U., Wildt J. Eds. Wiesbaden, Germany: Publishing House for Social Sciences, 1997, pp 65-85. DOI: https://doi.org/10.1007/978-3-322-95815-0_3

[3] J. Szempruch. Pedagogical teacher education in the face of education reform in Poland. Rzeszów, Poland: Publishing House of the University of Pedagogy in Rzeszów, Poland, 2000.

[4] N. Batechko. Contemporary approaches to modelling the content for training future University lecturers at graduate school. Educational process: theory and practice, Vol. 4, 5-20, 2013.

[5] L. Popov, I. Puchkova, P. Ustina. Formation of Psychological Readiness for Professional Activity: Competence Approach, International Electronic Journal of Mathematics Education, Vol. 11, No. 4, 819-827, 2016.

[6] K. Vlasenko, O. Chumak, I. Sitak, I. Lovianova, O. Kondratyeva. Training of mathematical disciplines teachers for higher educational institutions as a contemporary problem, Universal Journal of Educational Research, Vol. 7, No. 9, 1892-1900, 2019. doi: 10.13189/ujer.2019.070907

[7] L. Korenova. Blended learning in teaching mathematics at primary and secondary school, Online available from https://www.researchgate.net/publication/317851421_Blen ded learning in teaching_mathematics_at_primary_and s econdary_school

[8] Y. W. Lin, C. L. Tseng, P. J. Chiang. The Effect of Blended Learning in Mathematics Course, EURASIA Journal of Mathematics Science and Technology Education, Vol. 13, No. 3, 741-770, 2017. DOI 10.12973/eurasia.2017.00641a

[9] P. C. Holzweiss, B. Polnick, F. C. Lunenburg. Online in Half the Time: A Case Study with Online Compressed Courses, Innovative Higher Education, Vol. 44, No. 4, 299-315, 2019 , Online available from https://eric.ed.gov/?id=EJ1222651

[10] M. Tolegen, K. Tumanova, T. Shumeyko, S. Zhakaeva, K. Zhakaeva, S. Aysina. Technique for Formation of Future Teachers' Readiness for Their Professional and Pedagogic Cooperation, International Journal of Environmental \& Science Education, Vol. 11, No. 9, 2595-2605, 2016.

[11] V. Lyubov, V. Kochneva, T. Zulfugarzade, N. Aleksandrova, T. Shulga, L. Grudtsina, Y. Nikolaeva. Humanitarian component of professional training as factor of increasing student cultural level, Revista ESPACIOS, Vol. 39, No. 17, 23,2018 .

[12] N. Kushnir, N. Osipova, N. Valko, O. Litvinenko. The Experience of the Master Classes as a Means of Formation of Readiness of Teachers to Implement Innovation, ICTERI 2016, Kyiv, Ukraine, June 21-24, 200-214, 2016.

[13] A. Nurzhynska, V. Chernobrovkina. Can using social media as online learning platform increase student involvement? Development trends in pedagogical and psychological sciences: the experience of the countries of Eastern Europe and prospects of Ukraine, Baltija Publishing, Latvia, 58-75, 2018.

[14] A. M. Austin, L. Gustafson. Impact of course length on student learning, Journal of Economics and Finance Education, Vol. 5, No. 1, 26-37, 2006.

[15] K. Vlasenko, S. Volkov, I. Sitak, I. Lovianova and D. Bobyliev. Usability analysis of on-line educational courses on the platform "Higher school mathematics teacher", The International Conference on Sustainable Future: Environmental, Technological, Social and Economic Matters (ICSF 2020) E3S Web Conf., Vol. 166, Kryvyi Rih, Ukraine, 2020. DOI: 10.1051/e3sconf/202016610011

[16] J. G. Gaff. Preparing future faculty in the humanities and social sciences. A guide for change / J. G. Gaff, A. S. Pruitt-Logan, L. M. Sims, D. D. Denecke, Washington, DC, 2003.

[17] R. Rifandi (2013) Improving Students' Motivation in Learning Mathematics by Using Contextual Teaching Strategies https://www.researchgate.net/publication/236271785 Impr oving_Students'_Motivation_in_Learning_Mathematics_By _Using_Contextual_Teaching___trategies

[18] K. Vlasenko, O. Chumak, V. Achkan, I. Lovianova, O. Kondratyeva. Personal e-Learning Environment of a Mathematics Teacher. Universal Journal of Educational Research, Vol. 8, No. 8, 3527-3535, 2020. DOI: 10.13189/ujer.2020.080828.

[19] Y. Mao, V. Bhuse, Z Zhou, P. Pichappan, M. Abdel-Aty, Y. Hayafuji. Applied Mathematics and Algorithms for Cloud Computing and IoT, Mathematical Problems in Engineering, Vol. 2014, 2014, Online available from https://doi.org/10.1155/2014/946860

[20] A. Kolomiets, V. Klochko, O. Stahova. Professionally-Oriented Tasks as a Component of Fundamental Mathematical Training of Students of Technical Universities and Colleges, No. 26, 2019. DOI: https://doi.org/10.31475/ped.dys.2019.26.13

[21] V. Ochkov, K. Orlov, V. Voloshchuk. Thermal Engineering Studies with Exel, MathCad and Internet, By General Edition. N. Rogalev, Cham: Springer, 2016.

[22] M. Armbrust, A. Fox, R. Griffith et al. A view of cloud computing, Communications of the ACM, Vol. 53, No. 4, $50-58,2010$.

[23] P. Mell, T. Grance. The NIST definition of cloud computing: Recommendation of the National Institute of Standart and Technology, 2009, Online available from https://doi.org/10.6028/NIST.SP.800-145

[24] R. M. Lima, J. Dinis-Carvalho, R. M. Sousa, A. C. Alves, Management of interdisciplinary project approaches in engineering education: a case study, First Ibero-American Symposium on Project Approaches in Engineering Education - PAEE 2009, Guimarães, Portugal, 149-156, 
2019.

[25] P. Powell, W. Weenk. Project-led engineering education, Utrecht: Lemma, 2003.

[26] On-line course "Methods for Teaching Mathematics to Students in Technical Universities", Online available from http://formathematics.com/uk/kursy/nmk/mnmtzvo/

[27] Guide to Teaching Online Courses, Online available from http://www.nea.org/assets/docs/onlineteachguide.pdf

[28] Educational platform "Higher School Mathematics Teacher", Online available from http://formathematics.com/

[29] Kryvyi Rih State Pedagogical University: Assistant Internship Program, Online available from https: //drive.google.com/file/d/1KbR6aTQExwD6QeViRROxp9 UIhJOHIbxU/view

[30] The Bohdan Khmelnytsky National University of Cherkasy: Scientific and Pedagogical (assistant) Internship Program, Online available from https://drive.google.com/file/d/1rhQniMighg4SrJaceDKD0 YxuqmK68QKN/view

[31] National Pedagogical Dragomanov University: Scientific and Pedagogical Internship Program, Online available from https://fmf.npu.edu.ua/images $/ \% \mathrm{D} 0 \% 9 \mathrm{D} \%$ D0\%9F\%D0\%9F \%D0\%B2\%D0\%B8\%D0\%BC\%D0\% BE\%D0\%B3\%D0\%B8 \%D0\%BA\%D1\%80\%D0\%B8\% D1\%82\%D0\%B5\%D1\%80\%D1\%96\%D1\%97_\%D0\%BE $\% \mathrm{D} 1 \% 86 \% \mathrm{D} 1 \% 96 \% \mathrm{D} 0 \% \mathrm{BD} \% \mathrm{D} 1 \% 8 \mathrm{E} \% \mathrm{D} 0 \% \mathrm{~B} 2 \% \mathrm{D} 0 \% \mathrm{~B}$ $0 \% \mathrm{D} 0 \% \mathrm{BD} \% \mathrm{D} 0 \% \mathrm{BD} \% \mathrm{D} 1 \% 8 \mathrm{~F}$.pdf

[32] Berdyansk State Pedagogical University: Internship Program for Master students, Online available from http://bdpu.org/position-of-educationa/organization-of-edu cational-activities/

[33] K. Vlasenko, O. Chumak, I. Lovianova, D. Kovalenko and N. Volkova. Methodical requirements for training materials of on-line courses on the platform "Higher school mathematics teacher", The International Conference on Sustainable Future: Environmental, Technological, Social and Economic Matters (ICSF 2020) E3S Web Conf., Vol. 166, Kryvyi Rih, Ukraine, 2020

[34] M. Moore, A. Sheffield, H. Robinson, A. Phillips. Designing a course for teachers: Introduction to teaching online. Proceedings of SITE 2014 - Society for Information Technology \& Teacher Education International Conference, 583-588, 2014.

[35] I. Santos, A. A. Carvalho. Training and Monitoring: a two-stage training model in teacher professional development, Education \& Reality, Vol. 42, No.1, 2017, Online available from https://doi.org/10.1590/2175-623655 298.
[36] I. Lovianova, K. Vlasenko, A. Krasnoschok, D. Dmytriiev, R. Shponka R. Modeling of ICT competence formation of would-be mathematics teacher, Information Technologies and Learning Tools, Vol. 74, No. 6, 2019.

[37] K. Vlasenko, O. Chumak, I. Sitak, T. Kalashnykova, V. Achkan. CLIL Method to increase students' motivation in studying mathematics at higher technical school. Universal Journal of Educational Research, Vol. 8, No. 2, 362-370, 2020. DOI: 10.13189/ujer.2020.080205

[38] L. R. Porter. Developing an Online Curriculum: Technologies and Techniques, Hershey, PA: Information Science Publishing, 2004.

[39] N. Perogonchuk. Development model of professional competence of future psychologists Development trends in pedagogical and psychological sciences: the experience of countries of Eastern Europe and prospects of Ukraine: monograph / edited by authors, Baltija Publishing, Riga, Latvia, 151-170, 2018.

[40] N. Van Hattum-Janssen, The Role of teachers in projects, Project Approaches to Learning in Engineering Education: The Practice of Teamwork, Sense Publishers, Rotterdam, Netherlands, 161-176, 2012.

[41] S. Fernandes, M. A. Flores, R. M. Lima. Student Assessment in Project Based Learning, Project Approaches to Learning in Engineering Education: The Practice of Teamwork, Sense Publishers, Rotterdam, Netherlands, 147-160, 2012.

[42] T. Karsenti, C. Raby, S. Villeneuve, C. Gauthier. La formation des maitres et la manifestation de la compétence professionnelle à intégrer les technologies de l'information et des communications (TIC) aux fins de préparation et de pilotage d'activités d'enseignement-apprentissage, de gestion de l'enseignement et de développement professionnel, Montréal, QC: CRIFPE, 2007.

[43] E. Knowles, K. Kalata. A Model for Enhancing Online Course Development, Computer Science Innovate, Vol. 4, No. 2, 2007.

[44] M. Kebritchi, A. Lipschuetz, L. Santiague. Issues and Challenges for Teaching Successful Online Courses in Higher Education: A Literature Review, The Journal of Educational Technology Systems (ETS), Vol. 46, No. 1, 2017, Online available from https://doi.org/10.1177/0047239516661713.

[45] K. Vlasenko, V. Achkan, O. Chumak, I. Lovianova, T. Armash. Problem-based approach to develop creative thinking in students majoring in mathematics at teacher training universities. Universal Journal of Educational Research, Vol. 8, No. 7, 2853 - 2863, 2020. DOI: 10.13189/ujer.2020.080712. 